\title{
Penyebab kesulitan belajar geometri dimensi tiga
}

\author{
Rita Novita ${ }^{1 *}$, Rully Charitas Indra Prahmana ${ }^{2}$, Nurul Fajri ${ }^{1}$, Mulia Putra ${ }^{3}$ \\ ${ }^{1}$ Sekolah Tinggi Keguruan dan Ilmu Pendidikan Bina Bangsa Getsempena, Jl. Tanggul Krueng Aceh \\ No.34, Rukoh, Darussalam, Banda Aceh 23112, Indonesia. \\ ${ }^{2}$ Universitas Ahmad Dahlan, Jl. Pramuka Kav. 5, Pandeyan, Yogyakarta 55161, Indonesia \\ ${ }^{3}$ Hiroshima University, Higashihiroshima, T739-0046 Hiroshima Prefecture, Higashihiroshima, \\ Kagamiyama, 1 丁目3-2, Japan \\ * Corresponding Author. E-mail: rita@stkipgetsempena.ac.id, Telp: +6285260898187 \\ Received: 11 November 2017; Revised: 16 April 2018; Accepted: 27 April 2018
}

\begin{abstract}
Abstrak
Penelitian ini bertujuan untuk menyelidiki faktor-faktor yang menyebabkan kesulitan mahasiswa STKIP BBG dalam mempelajari geometri dimensi tiga. Penelitian ini menggunakan metode penelitian kualitatif studi kasus untuk mengkaji proses pembelajaran mahasiswa calon guru matematika di lingkungan STKIP BBG. Subjek dalam penelitian ini adalah 16 orang mahasiswa calon guru matematika STKIP BBG Semester II-IV Tahun Akademik 2016/2017 yang dipilih secara purposive sampling. Pengumpulan data dilakukan dengan menggunakan tehnik angket, tes, dan wawancara. Hasil penelitian menunjukkan bahwa kedua faktor internal dan ekternal memberi pengaruh terhadap kesulitan belajar yang dialami oleh mahasiswa pendidikan matematika STKIP BBG. Faktor internal sebagai penyebab kesulitan adalah faktor minat, bakat dan intelegensi mahasiswa yang memiliki persentase lebih dari 50\% tergolong rendah dan sangat rendah. Adapun faktor ekternal, diantaranya adalah aspek penggunaan metode mengajar oleh dosen dimana, penyampaian materi oleh dosen tanpa menyesuaikan kemampuan mahasiswa memiliki peran yang tinggi $(68.75 \%)$ dalam memunculkan kesulitan terhadap penguasaan konsep-konsep geometri dimensi tiga. Selain itu, pengalaman belajar geometri pada jenjang sekolah sebelumnya juga menjadi faktor lain yang mengakibatkan kesulitan belajar geometri dalam penelitian ini.
\end{abstract}

Kata Kunci: geometri dimensi tiga, faktor penyebab kesulitan belajar.

\section{The cause of difficulty in learning the three-dimensional geometry}

Abstract
This study aims to investigate the factors that cause STKIP BBG's prospective teachers difficulties in learning three-dimensional geometry. This research uses a case study qualitative research method to assess student learning process of prospective mathematics teachers in mathematics department at STKIP BBG. Subjects in this study were 16 prospective mathematics teachers in semester II - IV academic year 2016/2017 at STKIP BBG. The subjects were selected by purposive sampling. Data collection was done by using questionnaire technique, tests and interviews. The results showed that both internal and external factors had given effects toward learning difficulties experienced by mathematics education students at STKIP BBG. The internal factors are which suspected as the difficulty's cause are the interest factor; talent and intelligence where $50 \%$ of prospective mathematics teachers are in low and very low level. Meanwhile, the external factors, such as the use of teaching methods by lecturers where, the delivery of materials by lecturers without adjusting the ability of students have a high role (68.75\%) in raising difficulties on the mastery of three-dimensional geometry concepts. In addition, the experience of learning geometry at the previous school level is also another factor that leads to difficulties in learning geometry in this study.

Keywords: three-dimensional geometry, the factors that cause learning difficulties.

How to Cite: Novita, R., Prahmana, R., Fajri, N., \& Putra, M. (2018). Penyebab kesulitan belajar geometri dimensi tiga. Jurnal Riset Pendidikan Matematika, 5(1), 18-29. doi:http://dx.doi.org/10.21831/jrpm.v5i1.16836

Permalink/DOI: http://dx.doi.org/10.21831/jrpm.v5i1.16836 


\section{PENDAHULUAN}

Geometri adalah salah satu aspek penting dalam pembelajaran matematika yang harus dipahami oleh peserta didik, dikarenakan konsep geometri sangat erat kaitannya dengan kontek kehidupan sehari-hari (Clements \& Sarama, 2011; Panaoura, 2014; Rofii, Sunardi, \& Irvan, 2018). Selain itu, Geometri merupakan salah satu metode dasar yang tidak hanya digunakan orang untuk memahami dan menjelaskan lingkungan sekitar, tempat tinggal serta pergerakan manusia dalam lingkungannya (National Research Council, 2009) melainkan juga sebagai pondasi dasar yang memiliki peran penting dalam mendukung penguasaan konsep aljabar, bilangan, aritmatika serta konsep matematika selanjutnya (The National Mathematics Advisory Panel, 2008).

Untuk alasan inilah, peningkatan kemampuan berfikir geometri sangat penting dalam kemampuan berfikir tingkat tinggi, dan seharusnya hal ini dikembangkan dengan manipulasi dan interaksi spasial dalam kehidupan seharihari (Clements \& Sarama, 2011; Kamaliyah, Zulkardi, \& Darmawijoyo, 2013). Selanjutnya, konsep geometri terhubung dengan konsep matematika yang lain serta banyak terkait dengan situasi kehidupan sehari-hari (Clements \& Sarama, 2011; Bell dalam Astutik, 2017). Oleh karena itu, geometri merupakan suatu hal yang sangat penting untuk dipelajari dan dikuasai dalam pembelajaran matematika.

Geometri dimensi tiga merupakan bagian dari geometri yang membahas tentang bangun ruang atau bangun dimensi tiga (Iswadji, 2001; Negoro \& Harahap, 2014). Bangun ruang dapat didefinisikan sebagai bangun yang tidak seluruhnya terletak pada bidang karena mengandung tiga unsur yaitu panjang, lebar, dan tinggi, atau sering juga disebuut dengan (Negoro \& Harahap, 2014). Geometri dimensi tiga membahas mengenai objek-objek yang bersifat abstrak (Iswadji, 2001). Objek-objek tersebut seperti titik, garis, bidang, kubus, balok, bola, dan sebagainya dimana kesemuanya adalah objek-objek yang didapatkan melalui proses abtraksi berdasarkan benda-benda konkret yang terdapat dalam kehidupan sehari-hari (Clements \& Sarama, 2011; Couto \& Vale, 2014). Sehingga, sangat diharapkan bagi pendidik maupuan guru dalam mengembangkan pemahaman siswa pada konsep geometri sebaiknya dilakukan dengan aktivitas manipulasi objek-objek spasial atau benda-benda nyata (pengalaman kongkrit), brainstroming (konsep perumpamaan) sampai akhirnya siswa akan memiliki pengetahuan yang bersifat abstrak (abstract representation) mengenai geometri dimensi tiga (Browning, Edson, Kimani, Aslan-Tutak, \& Kimani, 2014) (Clements \& Sarama, 2011; Hwang, Su, Huang, \& Dong, 2009; Panaoura, 2014).

Hubungan pembelajaran geometri dengan teori belajar yang dikemukakan oleh Piaget yang dikutip Copeland (1984) menyatakan bahwa anak yang berumur 11 atau 12 tahun ke atas berada pada tahap operasi formal atau disebut juga periode hipotetik deduktif. Anak-anak pada periode ini sudah mampu untuk mengembangkan suatu pernyataan untuk menegaskan atau menyangkal sebagai hipotesis kemudian membuktikan hipotesis itu melalui perbandingan antara akibat-akibat deduktifnya dengan faktafakta dalam cara berpikirnya (Copeland, 1984). Pada tahap operasi formal, anak juga dapat mengoperasikan argumen-argumen tanpa dikaitkan dengan benda-benda konkret. Anak mampu bernalar tanpa harus berhadapan dengan objek atau peristiwa langsung (George, 2017; Ojose, 2008; Ryandi, Somakim, \& Susanti, 2018). Tetapi pada kenyataannya, berdasarkan hasil observasi sederhana selama proses perkuliahan Geometri Ruang atau matakuliah yang berkaitan dengan geometri ruang pada mahasiswa calon guru matematika (pendidikan matematika) STKIP Bina Bangsa Getsempena (BBG), mahasiswa cenderung kesulitan dalam membayangkan konsep keruangan, menggambar atau membuat ilustrasi dari suatu bangun dimensi tiga (Gambar $1 \&$ 2) sehingga sering sekali dosen harus membawa model bangun ruang atau alat peraga konkret dimensi tiga untuk membantu mahasiswa dalam memahami konsep geometri dimensi tiga yang ingin dijelaskan.

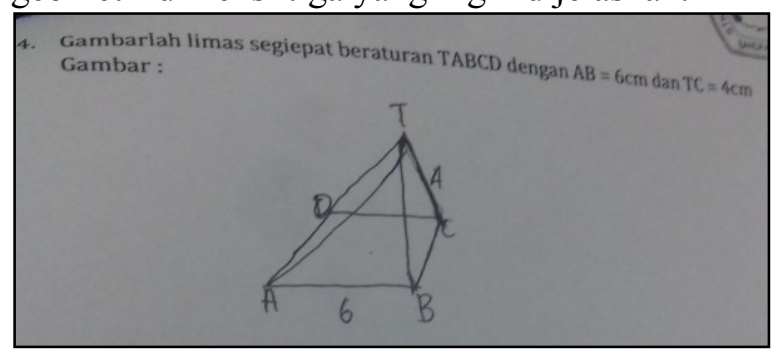

Gambar 1. Contoh Kesalahan dalam Menggambar Bangun Geometri Ruang

Hal ini juga didukung oleh pernyataan dan informasi dosen pengampu matakuliah geometri maupun dosen matematika lainnya pada program studi pendidikan matematika STKIP BBG yang diperoleh pada studi pendahuluan 
penelitian ini.

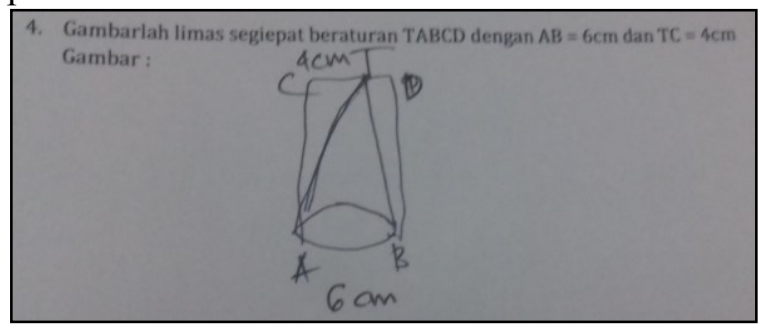

Gambar 2. Kesalahan dalam Menggambar Bangun Geometri Ruang

Selain itu, kesulitan juga dialami mahasiswa ketika mereka diminta untuk menyelesaikan permasalahan geometri yang berkaitan dengan pembuktian. Kesulitan tersebut ditunjukkan mahasiswa melalui kesalahan-kesalahan yang dilakukan mereka pada saat mengerjakan soal- soal yang berkaitan dengan geometri dimensi tiga. Kesulitan yang dialami siswa tersebut kemudian berimbas pada penguasaan materi geometri sendiri maupun terhadap konsep lain dalam matematika (misalnya pada matakuliah kalkulus lanjut, geometri Analitik Ruang), hal ini ditandai oleh rendahnya nilai mahasiswa dalam setiap pelaksanaan tes maupun ujian akhir semester dimana rata-rata mencapai $62 \%$ mahasiswa mendapatkan nilai C \& D pada MK terkait geometri (Sumber Data DPNA P.MAT STKIP BBG tahun 2013-2016).

Kesulitan mahasiswa dalam mempelajari geometri dimensi tiga merupakan isu penting untuk diselesaikan, karena berpengaruh terhadap kemampuan mahasiswa dalam memahami materi matematika selanjutnya (Acharya \& Ghose, 2015). Jika dibiarkan, kesulitan dalam pembelajaran dimensi tiga, dapat membuat penguasaan matematika calon guru matematika STKIP BBG berkualitas rendah. Hal ini juga didukung oleh adanya temuan dari banyak penelitian mengenai kesiapan calon guru matematika dalam penguasaan konsep matematika khususnya aspek geometri yang masih terkendala (AslanTutak \& Adams, 2015; Browning et al., 2014; Couto \& Vale, 2014; Leung, Ding, Leung, \& Wong, 2013; Robichaux-Davis \& Guarino, 2016; Romano, 2017). Oleh karenanya, permasalahan kesulitan dalam pembelajaran geometri dimensi tiga ini dianggap urgent untuk dilakukan kajian lebih mendalam dalam suatu penelitian dengan terlebih dahulu menemukan apa saja faktor penyebabnya yang kemudian menjadi bahan pertimbangan bagi pendidik (guru atau dosen) dalam melakukan perbaikan mengajar atau Remidial Teaching. Hal ini sejalan dengan apa yang disampaikan Departemen
Pendidikan dan Kebudayaan (2012) bahwa jika peserta didik mengalami kesulitan maka kesulitan tersebut muncul dalam bentuk kesalahankesalahan yang dibuat oleh peserta didik. Sehingga penting bagi pendidik untuk menganalisis kesulitan dan mencarikan penyebabnya kesulitan yang dialami peserta didik (Kereh, Sabandar, \& Tjiang, 2013; Nurhikmayati, 2017; Syahrir, Kusnadin, \& Nurhayati, 2013).

Pada dasarnya, penyebab kesulitan belajar dipengaruhi oleh dua faktor yaitu faktor intern (faktor dari dalam diri peserta didik) dan faktor ekstern (yaitu faktor yang berasal dari luar baik itu keluarga, sekolah maupun lingkungan (Hamalik, 2015). Oleh karena itu, faktor tersebut harus dikaji lebih mendalam sebagai upaya mengatasi kesulitan belajar peserta didik khususnya calon guru pendidikan matematika. Association for Children and Adult with Learning Disability (ACALD) menyebutkan bahwa "kesulitan belajar adalah suatu kondisi ketidak-mampuan yang nyata pada orang-orang yang memiliki intelegensi rata-rata hingga superior, yang memiliki system sensori yang cukup, dan kesempatan belajar yang cukup pula" (Pujaningsih, 2011). Disisi lain, Syahrir, Kusnadin, \& Nurhayati (2013) menegaskan bahwa kesulitan belajar dapat didefinisikan sebagai suatu kesenjangan antara potensi yang dimiliki peserta didik dengan prestasi yang diraih dalam menyelesaikan tugas-tugas akademik. Berdasarkan definisi tersebut, kesulitan belajar yang dimaksud dan dikaji dalam penelitian ini adalah suatu kondisi ketidakmampuan mahasiswa calon guru pendidikan matematika STKIP BBG dalam mempelajari dan memahami konsep geometri ruang atau geometri tiga dimensi.

Kesulitan belajar pada dasarnya dapat dibagi dua aspek yaitu kesulitan belajar akademik dan kesulitan belajar perkembangan (Abdurrahman dalam Syahri, et al. 2013). Pada proses pembelajaran di kelas khususnya, kesulitan akademik perlu dikaji lebih dalam karena sangat berpengaruh pada pencapaian prestasi belajar peserta didik. Kesulitan belajar yang terkait dengan akademik ditandai dengan adanya kegagalan untuk mencapai prestasi akademik sesuai dengan apa yang diharapkan. Kegagalan atau ketidakmampuan tersebut meliputi kegagalan penguasaan ketrampilan membaca, menulis, maupun bermatematisasi. Kesulitan belajar akademik tersebut dapat diketahui oleh pendidik maupun orang tua ketika anak tidak mampu menunjukkan atau mencapai kemampuan-kemampuan yang berkaitan akademik tersebut 
(Departemen Pendidikan dan Kebudayaan, 2012). Pada proses pembelajaran misalnya, peserta didik yang mengalami kesulitan belajar dapat diketahui melalui kriteria-kriteria atau ciriciri tertentu, diantaranya adalah seperti apa yang disampaikan oleh Surya dan Suryabrata (Syahrir et al., 2013) berikut ini: (1) menujukkan adanya hasil belajar yang rendah; (2) hasil yang dicapai tidak sesuai dengan usaha yang dilakukan; (3) lambat dalam menyelesaikan tugas-tugas kegiatan belajar; serta (4) adanya gangguan prestasinya. Sehingga jika peserta didik menunjukkan salah satu dari keempat ciri tersebut dalam proses pembelajaran, maka dapat diyakini bahwa peserta didik sedang mengalami kesulitan dalam belajarnya.

Berdasarkan permasalahan yang dialami oleh mahasiswa calon guru pendidikan matematika STKIP BBG dalam pembelajaran geometri dimensi tiga serta beberapa karakteristik kesulitan belajar yang dialaminya, maka dianggap perlu dan penting untuk melakukan kajian mendalam terhadap faktor-faktor penyebab kesulitan belajar tersebut. Sehingga rumusan masalah yang dikaji dalam penelitian ini adalah apa sajakah factor-faktor yang menyebabkan mahasiswa calon guru matematika STKIP BBG mengalami kesulitan dalam penguasaan konsep geometri dimensi tiga?

\section{METODE}

Penelitian ini dilakukan dengan menggunakan pendekatan penelitian kualitatif, dengan metode studi kasus. Prahmana (2017) menyatakan bahwa penelitian studi kasus merupakan salah satu metode penelitian yang bertujuan untuk menyelidiki secara cermat suatu program, peristiwa, aktivitas, proses, atau sekelompok individu pada suatu waktu tertentu.

Pada tahap awal penelitian diakukan dengan memilih masalah yaitu menganalisis faktor-faktor penyebab kesulitan mahasiswa calon guru matematika dalam mempelajari geometri dimensi tiga. Setelah permasalahan dirumuskan, Penelitian dilanjutkan dengan melakukan studi literature terhadap data yang diperlukan untuk menjawab rumusan masalah yaitu faktor-faktor penyebab kesulitan belajar geometri dimensi tiga. Pada tahap ini, peneliti mencoba menyusun instrument angket penelitian berdasarkan studi literature yang dilakukan. Instrumen angket yang dikembangkan digunakan untuk mengetahui informasi mengenai faktor-faktor yang diduga dapat menjadi penyebab kesulitan belajar geometri dimensi tiga. Hasil yang diperoleh pada Angket penelitian juga digunakan untuk menentukan subjek dalam penelitian ini yaitu mahasiswa calon guru yang menyatakan bahwa memiliki kesulitan dalam mempelajari geometri dimensi tiga.

Angket pada penelitian ini dikembangkan dari indicator faktor-faktor penyebab kesulitan belajar yang telah dimodifikasi berdasarkan instrument penelitian Syahrir et al. (2013) sebelumnya. Pertanyaan dan pernyataan yang dikembangkan dalam angket juga dilakukan validasi isi kepada dua orang teman sejawat (dosen pendidikan matematika STKIP BBG) untuk dibaca dan diberikan masukan sebelum angket digunakan untuk pengambilan data. Berdasarkan saran dan masukan dari dua validator, angket kemudian dilakukan revisi sehingga secara khusus kisi-kisi instrument angket setelah dilakukan revisi dapat kita lihat pada Tabel 1.

Bersamaan dengan penyusunan angket, peneliti juga menyusun dan merancang tes geometri dimensi tiga (tes diagnostic) yang digunakan untuk mendiagnosis jenis-jenis kesulitan yang dialami oleh mahasiwa calon guru pendidikan matematika STKIP BBG pada geometri dimensi tiga. Instrumen tes diagnostic ini dikembangkan berdasarkan kompetensi dasar geometri dimensi tiga yang seharusnya dikuasi oleh mahasiswa pada jenjang sebelumnya dan pada saat perkuliahan. Kompetensi penguasaan geometri dimensi tiga ini disesuaikan dengan kurikulum sekolah menengah atas dan capaian pembelajaran matakuliah geometri dimensi tiga yaitu diantaranya adalah: (1) Menurunkan rumus untuk menentukan luas permukaan dan volume bangun ruang sisi datar (kubus, balok, prisma, dan limas); (2) Menyelesaikan masalah kontekstual yang berkaitan dengan luas permukaan dan volume bangun ruang sisi lengkung (tabung, kerucut, dan bola), serta gabungan beberapa bangun ruang sisi lengkung; (3) Menentukan kedudukan titik, garis, dan bidang dalam ruang dimensi tiga; (4) Menentukan jarak dari titik ke garis dan dari titik ke bidang, besar sudut antara garis dan bidang dan antara dua bidang dalam ruang dimensi tiga. Kemudian setelah instrumen angket dan tes diagnostik selesai disusun, maka tahap penelitian dilanjutkan ke tahap pengumpulan data atau tahap distribusi angket dan pelaksanaan tes diagnostik geometri dimensi tiga.

Proses pengambilan dan pengumpulan data dilakukan atas izin dari pihak STKIP BBG untuk mengadakan penelitian. Sebagai langkah awal 
penelitian, peneliti memilih subjek penelitian dengan purposive sampling. Subjek penelitian yang terpilih adalah mahasiswa yang telah mengisi kuesioner dan setelah dilakukan analisis terhadap kuesioner maupun diskusi hasil studi mata kuliah geometri ruang dengan dosen pengampu mata kuliah tersebut sehingga dapat diyakini kebenarannya secara statistik bahwa benar subjek penelitian mengalami kesulitan dalam mempelajari geometri dimensi tiga berdasarkan indikator yang tertera pada angket.

Sehingga berdasarkan hasil angket diketahui bahwa subjek penelitian yang dianalisis faktor penyebab kesulitannya adalah sebanyak 16 orang mahasiswa semester II-IV tahun akademik 2016/2017. Pemilihan subjek penelitian dibatasi hanya pada semester II-IV dikarenakan mahasiswa pada semester tersebut sudah mempelajari konsep-konsep yang berkaitan dengan konsep dasar geometri dimensi tiga (geometri ruang) maupun geometri ruang lanjutan.

Pada tahap selanjutnya, data hasil angket ini kemudian diolah untuk diketahui tingkat kesulitan siswa dalam mempelajari dimensi tiga ditinjau dari faktor-faktor penyebab kesulitan belajar siswa yang terdiri dari faktor internal dan faktor eksternal. Sedangkan terhadap subjek penelitian yang telah terpilih dan diyakini memiliki kesulitan dalam memahami geometri dimensi tiga, diberikan tes diagnostik geometri dimensi tiga. Tes diagnostik geometri dimensi tiga ini bertujuan untuk untuk melihat jenisjenis kesulitan belajar geometri dimensi tiga apa saja yang dihadapi oleh subjek penelitian/ mahasiswa dalam bentuk kesalahan-kesalahan yang dilakukan mahasiswa dalam menjawab soal yang berkaitan dengan konsep dan prinsip sehingga dapat diketahui tingkat kesulitan belajar siswa ditinjau dari konsep dan prinsip. Kemudian setelah data Angket diperoleh, maka dilakukan analisis data dengan menggunakan tehnik analisis data deskriptif kualitatif sebagaimana disampaikan oleh Miles dan Huberman dalam (Sugiyono, 2015) yang meliputi beberapa tahapan berikut ini:

\section{Data Reduction (Reduksi Data)}

Reduksi data adalah proses pemilihan dan penyederhanaan data-data yang berasal dari catatan-catatan lapangan. Reduksi data meliputi kegiatan-kegiatan seperti meringkas data, mengkode, menelusur tema, dan membuat gugusgugus (Sugiyono, 2015). Hal ini dilakukan untuk memperoleh informasi yang jelas dari data yang didapat sehingga kesimpulan yang di ambil nantinya dapaat dipertanggung jawabkan. Reduksi data dalam penelitian ini dilakukan dengan menganalisis data hasil angket yang dibagikan kepada 16 responden yang nantinya dipergunakan untuk menentukan faktor-faktor yang menyebabkan kesulitan belajar geometri dimensi tiga dari subjek penelitian tersebut.

\section{Data Display (Penyajian Data)}

Penyajiaan data merupakan tahap selanjutnya setelah reduksi data dilakukan. Penyajian data ini berupa penggabungan informasi-informasi yang sudah didapat dalam bentuk teks naratif. Pada tahap ini dilakukan dengan menyajikan data hasil angket yang telah diisi oleh mahasiswa serta menyajikan hasil jawaban siswa yang dilakukan pada tahapan selanjutnya (Sugiyono, 2015). Membandingkan data hasil tes diagnostik dan data hasil tes lisan, membandingkan data hasil tes diagnostik, data hasil tes lisan dan data hasil wawancara, Membandingkan data hasil tes diagnostik, data hasil tes lisan, dan data hasil pengamatan (catatan siswa selama proses pembelajaran geometri dimensi tiga) Dalam penelitian ini, peneliti tidak hanya menggunakan teks naratif dalam menyajikan data penelitian. Akan tetapi, mendukungnya dengan matriks yang berisi pertanyaan penelitian, jawaban informan, teori yang kiranya berkaitan dan interpretasi peneliti terhadap jawaban informan dan teori yang didapat.

\section{Conclusion Drawing (Penarikan Kesimpulan)}

Penarikan kesimpulan merupakan langkah akhir yang dilakukan dalam proses penelitian. Penarikan kesimpulan ini mengerucut sesuai pengalaman observasi dan data-data yang didapatkan. Kesimpulan semakin jelas apabila semua data sudah melalui proses pengumpulan, analisis dan penyajian yang baik dan benar. Selain analisis data secara deskriptif kualitatif, data faktor-faktor penyebab kesulitan mahasiswa calon guru matematika STKIP BBG juga Dianalisa secara kuantitaif. Skor yang diperoleh dari hasil pengisian angket untuk masing-masing faktor tersebut kemudian dikategorikan seperti tampak pada Tabel 2.

\section{Tabel 2. Skala Nilai Kategori}

\begin{tabular}{cc}
\hline Interval & Kategori \\
\hline $\mathrm{X} \geq \overline{\bar{x}}+1 . \mathrm{SBx}$ & Sangat Tinggi \\
$\bar{x} \leq \mathrm{X}<\bar{x}+1 . \mathrm{SBx}$ & Tinggi \\
$\bar{x}-1 . \mathrm{SBx} \leq \mathrm{X}<\bar{x}$ & Kurang \\
$\mathrm{X}<\overline{\bar{x}}+1 . \mathrm{SBx}$ & Rendah \\
\hline
\end{tabular}

Sumber: Modifikasi Syahrir et al. (2013) 
Jurnal Riset Pendidikan Matematika, 5 (1), 2018 - 23

Rita Novita, Rully Charitas Indra Prahmana, Nurul Fajri, Mulia Putra

Ket:

X: Skor yang dicapai siswa

$\overline{\bar{x}}$ : Rerata skor keseluruhan siswa

SBx: Simpangan baku skor keseluruhan siswa

\section{HASIL DAN PEMBAHASAN}

Instrumen angket disusun berdasarkan indikator yang mencakup aspek faktor internal maupun aspek faktor eksternal sebagaimana tertera pada Tabel 1. Instrument angket sebelum diujicobakan telah terlebih dahulu dilakukan proses validasi pakar baik dari segi isi maupun konstruks. Instrumen angket yang disusun bersifat terbuka dan tertutup. Pada awal penyusunannya instrumen angket menyediakan sebanyak 20 butir pertanyaan, namun berdasarkan masukan dari pakar pada proses validasi, 3 pertanyaan bersifat tidak valid karena tidak sesuai dengan indicator yang ditetapkan dan memiliki maksud yang sama dengan pertanyaan lainnya. Pada tabel Reliability Statistics pada kolom Cronbach's Aplha diperoleh nilai korelasi sebesar 0.612 dengan banyak item 17 per koesioner dan jumlah responden 9 orang (pada uji validitas dan reliabilitas). Nilai ini sangat bagus atau tergolong kuat. Sehingga dapat disimpulkan bahwa angket yang disusun dalam penelitian ini sudah bisa dibagikan ke responden yang menjadi subjek penelitian, karena hasil pengukurannya sudah dapat dipercaya berdasarkan nilai korelasi yang diperoleh sebesar 0.612.

Berdasarkan hasil analisis data angket, total skor yang diperoleh oleh responden sangat bervariasi, dimana skor tertinggi adalah 84.4, skor terendah adalah 59.8, dengan nilai rata-rata 71.1 dan simpangan baku 7.5. Data yang diperoleh tersebut dilakukan analisis secara deskriptif kualitatif serta kuantitatif. Hasil analisis data penelitian menunjukkan bahwa hasil analisis secara kuantitatif terhadap faktor-faktor penyebab kesulitan belajar geometri dimensi tiga dari setiap responden. kategori masing-masing faktor baik secara internal maupun ekternal dikategorikan dan disajikan dalam bentuk persentase dengan skala sangat tinggi sampai dengan sangat rendah. Untuk data lengkapnya, dapat dilihat pada Tabel 3.

Data pada Tabel 3 menunjukkan bahwa faktor yang menyebabkan kesulitan belajar geometri dimensi tiga pada mahasiswa calon guru matematika STKIP BBG terdiri dari faktor intern dan faktor eksternal. Ditinjau dari faktor intern siswa, dapat dilihat bahwa rata-rata responden memiliki minat, bakat dan intelegensi yang tergolong rendah dimana lebih dari $50 \%$ berada pada kategori rendah. Hal ini menunjukkan bahwa faktor minat, bakat dan intelegensi ini memiliki pengaruh yang cukup tinggi sebagai faktor penyebab terjadinya kesulitan belajar geometri dimensi tiga mahasiswa matematika STKIP BBG. Pada sisi lain, data Tabel 3 menunjukkan bahwa lebih dari 56\% responden pada dasarnya memiliki motivasi yang sangat tinggi untuk mempelajari geometri dimensi tiga.

Secara lebih rinci, motivasi belajar dalam penelitian ini difokuskan pada aspek intrinsik peserta didik yang menjadi bagian dari faktor internal kesulitan belajar. Motivasi intrinsik menunjukkan adanya hasrat dan keinginan untuk berhasil (Hook \& Vass dalam Astutik, 2017, p. 58) yang ditunjukkan melalui perhatian yang lebih terhadap pembelajaran geometri dimensi tiga dan usaha-usaha rasional yang dilakukan untuk mempelajari materi geometri dimensi tiga. Berdasarkan respon subjek penelitian terhadap pertanyaan nomor 13 terkait aspek motivasi yaitu usaha yang dapat dilakukan untuk mengatasi kesulitan dalam mempelajari belajar geometri, diperoleh informasi bahwa $100 \%$ responden memiliki usaha dan kiat masing-masing yang cukup efektif dalam belajar geometri dimensi tiga.

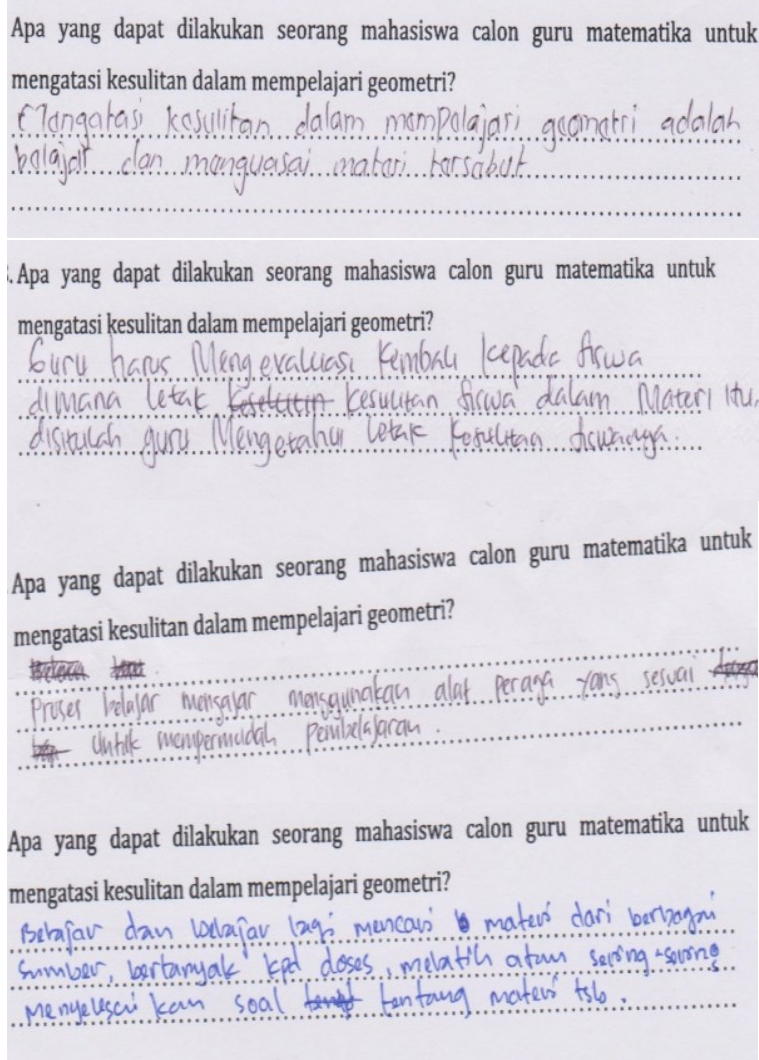

Gambar 3. Jawaban Responden Berkaitan dengan Motivasi Belajar Geometri Dimensi Tiga 
Jurnal Riset Pendidikan Matematika, 5 (1), 2018 - 24

Rita Novita, Rully Charitas Indra Prahmana, Nurul Fajri, Mulia Putra

Hasil angket terbuka dan wawancara mendapatkan informasi terkait usaha yang dilakukan mahasiswa tersebut seperti (1) mengulang kembali materi dasar geometeri dimensi tiga agar mudah untuk mempelajari geometri dimensi tiga pada tingkat universitas, (2) bertanya kepada dosen jika ada materi yang tidak dipahami; (3) memperbanyak latihan dengan seringsering menyelesaikan soal-soal terkait geometri dimensi tiga; dan beberapa alasan lainnya (Gambar 4). Keadaan ini menjelaskan bahwa, secara sadar mahasiswa responden memiliki motivasi besar dalam usaha belajar geometri dimensi tiga meskipun mereka tetap masih mengalami kesulitan dalam memahami materi tersebut. Terkait hal ini, penelitian Ahmad (2016, p. 259) menunjukkan bahwa besar pengaruh langsung motivasi berprestasi siswa terhadap prestasi belajar hanya sebesar 0,0025\%, selebihnya dipengaruhi oleh faktor lain. Keadaan ini mengindikasikan bahwa, meskipun peserta didik memiliki motivasi yang besar dalam pembelajaran namun jika aspek lain yang mempengaruhi pencapaian prestasi belajar (seperti minat, intelegensi, dan lain-lain) berada pada tingkatan pencapaian yang rendah, maka sangat memungkinkan akan menyebabkan kesulitan belajar atau pencapaian prestasi belajar yang rendah.

Hal ini sejalan dengan apa yang disampaikan Dalyono (2012, p. 240) dan Astutik (2017, p. 58) bahwa belajar yang tidak dibarengi oleh keinginan yang kuat/minat akan menghasilkan suatu proses pembelajaran yang tidak sesuai dengan siswa, sehingga siswa merasa tidak senang dan kurang yakin dalam mengikuti pembelajaran yang berimbas pada kurangnya kecakapan siswa serta menghambat kinerja otak yang akhirnya akan menimbulkan kesulitan belajar.

Aspek minat dapat dilihat dari ketertarikan peserta didik terhadap suatu hal dibandingkan yang lainnya, dapat pula ditunjukkan dari perhatian lebih besar yang diberikan kepada suatu objek (Nitko \& Brookhart, 2011, p. 448). Sehingga aspek minat yang dilihat dalam penelitian difokuskan pada dua hal yaitu Ketertarikan pada pembelajaran dimensi tiga serta sikap yang diberikan kepada pembelajaran geometri dimensi tiga (Nitko \& Brookhart, 2011, p. 449). Berdasarkan dua hal tersebut, hasil data angket menunjukkan bahwa Minat mahasiswa calon guru pendidikan matematika STKIP BBG terhadap pembelajaran geometri dimensi tiga ratarata tergolong sangat rendah mencapai 56,25\%.

Hal lain yang mempengaruhi pembelajaran geometri dimensi tiga adalah bakat. Seorang peserta didik yang mempelajari sesuatu hal di luar bakatnya biasanya mudah putus asa, bosan, serta akhirnya menimbilkan kecenderungan tidak senang. Terkait aspek bakat yang dimiliki oleh mahasiswa calon guru matematika STKIP BBG pada bidang matematika khususnya materi geometri dimensi tiga, berdasarkan hasil angket diperoleh bahwa sebanyak $62,5 \%$ berada pada kategori rendah dan sangat rendah. Hal ini didukung dengan jawaban mahasiswa responden terhadap pertanyaan yang diajukan dalam angket maupun wawancara terkait aspek bakat tersebut, yaitu (1) mereka tidak mampu menjelaskan apa saja materi atau topic yang dipelajari pada saat belajar geometri dimensi tiga dengan alasan sudah lupa, tidak berkesan, tidak senang belajar serta tidak paham saat dijelaskan; (2) lebih dari $76 \%$ mahasiswa menyatakan masih memiliki kendala dan susah dalam menyelesaikan soalsoal yang berkaitan dengan geometri dimensi tiga, namun malas dan malu untuk bertanya kepada dosen karena berbagai alasan. Diantara alasan yang disebutkan mahasiswa responden adalah merasa malu karena merasa materi yang dikuasai sudah jauh tertinggal dibandingkan kawan-kawan yang lain.

Selanjutnya, aspek lain dari faktor internal yang mempengaruhi adalah aspek intelegensi. Informasi terkait aspek intelegensi dalam penelitian ini digali melalui tiga pertanyaan yang memuat 2 indikator aspek intelegensi yaitu:

\section{Indikator I: Kecakapan dalam Menyelesaikan Persoalan Dimensi Tiga}

Q6. Apakah anda memiliki kesulitan dalam mempelajari materi geometri dimensi tiga ketika Anda duduk diperguruan tinggi saat ini? Tuliskan kesulitan apa saja yang Anda hadapi!

Q8. Apakah Anda memiliki masalah/kendala dalam menyelesaikan masalah matematika terkait geometri dimensi tiga saat di perguruan tinggi? Tuliskan kendala/masalah yang Anda hadapi/rasakan! 
Jurnal Riset Pendidikan Matematika, 5 (1), 2018 - 25

Rita Novita, Rully Charitas Indra Prahmana, Nurul Fajri, Mulia Putra

Tabel 3. Persentase Faktor-Faktor yang Mengakibatkan Kesulitan Mempelajari Geometri Dimensi Tiga

\begin{tabular}{|c|c|c|c|c|c|}
\hline \multicolumn{6}{|c|}{ Faktor Internal (Diri Siswa) } \\
\hline \multirow{2}{*}{ No. } & \multirow{2}{*}{ Aspek } & \multicolumn{4}{|c|}{$\%$ Berdasarkan Kategori } \\
\hline & & Sangat Tinggi & Tinggi & Rendah & Sangat Rendah \\
\hline a. & Minat & 0 & 0 & 43.75 & 56.25 \\
\hline b. & Motivasi & 31.25 & 25 & 31.25 & 12.5 \\
\hline c. & Bakat & 18.75 & 18.75 & 50 & 12.5 \\
\hline d. & Intelegensi & 12.5 & 31.25 & 50 & 6.25 \\
\hline & Rata-Rata & 15.63 & 18.75 & 43.75 & 21.88 \\
\hline \multicolumn{6}{|c|}{ Faktor Ekternal (Pengajar\& Lingkungan Sekolah) } \\
\hline \multirow{2}{*}{ No. } & \multirow{2}{*}{ Aspek } & \multicolumn{4}{|c|}{$\%$ Berdasarkan Kategori } \\
\hline & & Sangat Tinggi & Tinggi & Rendah & Sangat Rendah \\
\hline a. & Kualitas Pengajar & 0 & 62.5 & 25 & 12.5 \\
\hline b. & Metode pembelajaran & 31.25 & 0 & 68.75 & 0 \\
\hline c. & Fasilitas & 75 & 0 & 25 & 0 \\
\hline d. & Gedung/ruang belajar & 43.75 & 0 & 56.25 & 0 \\
\hline & Rata-Rata & 37.50 & 15.63 & 43.75 & 3.13 \\
\hline
\end{tabular}

Indikator II: Penguasaan Materi Geometri

Dimensi Tiga pada Jenjang Pendidikan

Sebelumnya

Q7. Apakah anda memiliki kesulitan dalam mempelajari materi geometri dimensi tiga ketika masih duduk di SMP dan SMA? Tuliskan kesulitan apa saja!

Terkait aspek intelegensi, 56.25\% mahasiswa memiliki aspek intelengensi dalam kategori rendah dan sangat rendah, artinya mereka memiliki masalah baik dalam penguasaan materi geometri dimensi tiga maupun dalam menyelesaikan permasalahan geometri dimensi tiga baik pada jenjang sebelunya maupun pada jenjang perguruan tinggi. Rendahnya persentase aspek intelegensi atau intelektual ini, sangat berpengaruh terhadap penguasaan materi geometri dimensi tiga pada tahap selanjutnya. Jika hal ini tidak diketahui oleh pendidik dan tidak dilakukan penanganan yang tepat maka bisa dipastikan peserta didik akan mengalami kesulitan dalam mempelajari geometri dimensi tiga.

Selanjutnya, berkaitan dengan kesulitan yang dihadapi para mahasiswa calon guru terkait aspek intelensi, sudah semestinya menjadi perhatian untuk dicarikan soslusinya, karena banyak studi penelitian dunia yang membahas mengenai kemampuan yang dimiliki calon guru khusunya guru bidang matematika dan hubungannya dengan kesiapan dalam memberikan pengajaran setelah mereka menjadi guru (AslanTutak \& Adams, 2015; Browning et al., 2014; Couto \& Vale, 2014; Leung et al., 2013; Robichaux-Davis \& Guarino, 2016; Romano, 2017). Pada dasarnya, ditinjau dari kesulitan yang diakibatkan faktor intelegensi pemahaman terhadap konsep dan prinsip, maka dapat disimpulkan bahwa cukup tingginya tingkat kesulitan belajar yang dialami oleh mahasiswa calon guru pendidikan matematika STKIP BBG secara ratarata dalam menguasai geometri dimensi tiga disebabkan oleh kesulitan mahasiswa dalam memberikan contoh konsep tertentu, kesulitan mahasiswa dalam memberikan nama bangun ruang, kesulitan dalam klasifikasi, ketidakterampilan mahasiswa dalam keterampilan dasar dan kesalahan kalkulasi, kesalahan prosedur, dan kurangnya pemahaman mahasiswa terhadap konsep dasar sehingga siswa mengalami kesulitan dalam memahami dan menggunakan prinsip. Hal ini jika dikaji lebih mendalam sesuai dengan hasil penelitian terdahulu yang menyebutkan bahwa pada dasarnya terdapat dua hal utama kesulitan yang dialami oleh siswa pada saat mempelajari geometri yaitu miskonsepsi terhadap konsep dan prinsip geometri (Ada \& Kurtuluş, 2010; Kabaca, Karadag, \& Aktumen, 2011; Novita \& Niawati, 2016; Özerem, 2012; Sutiarso, Nurhanurawat, \& Coesamin, 2008).

Pada aspek intelegensi ini, salah satu indikator intelegensi yang ditelusuri adalah penguasaan materi geometri dimensi tiga mahasiswa pada jenjang pendidikan sebelumnya. Berdasarkan analisis data angket perbutir pertanyaan dan hasil wawancara terkait indikator tersebut didapatkan informasi bahwa $81,25 \%$ mahasiswa mengatakan bahwa memiliki kesulitan pemahaman geometri dimensi tuga pada saat berada pada jenjang SMA. Beberapa hal utama yang menjadi penyebabnya kesulitan yang disampaikan mahasiswa responden adalah: (1) penjelasan guru yang sulit untuk dipahami oleh responden (padahal sudah diperhatikan dengan baik) sehingga 
mereka kesulitan untuk mengikuti materi ini (sulit mengikuti ketika guru menjelaskan; guru terlalu cepat menjelaskan; guru kurang bisa menjelaskan kepada siswa, guru menjelaskan tidak terstruktur, (2) kurangnya penggunaan media konkrit seperti alat peraga oleh guru sehingga hal yang bersifat abstrak susah dibayangan oleh responden (kesulitan dalam melukis bangun-bangun ruang, kesulitan membayangkan benda-benda/unsur-unsur yang tidak nampak, siswa dituntut menghayal), (3) kurangnya aktivitas pembelajaran yang bermakna sehingga pembelajaran hanya terkesan pada penguasaan sejumlah teori (kesulitan menghafal rumus, kesulitan dalam memahami dan menyelesaikan soal-soal yang terkait dengan dimensi tiga). Dari informasi ini, diketahui bahwa pengalaman belajar para responden pada jenjang sebelumnya memiliki pengaruh yang cukup besar terhadap kesulitan belajar geometri dimensi tiga yang dialami oleh mahasiswa calon guru matematika STKIP BBG.

Berdasarkan analisis terhadap faktor internal tersebut, diperoleh bahwa terdapat tiga faktor internal yaitu minat, bakat dan interlegensi yang diduga menjadi faktor penyebab kesulitan belajar yang dialami oleh mahasiswa calon guru matematika STKIP BBG.

Selanjutnya, jika ditinjau dari factor eksternal para mahasiswa calon guru matematika STKIP BBG berdasarkan Tabel 3 dapat dilihat pada aspek kualitas pengajar dalam hal ini adalah dosen yang mengajarkan materi geometri dimensi tiga, $62,5 \%$ berada pada kategori tinggi. Aspek kualitas ini difokuskan pada penguasaan dosen terhadap materi serta kejelasan menyampaikan saat menjelaskan. Untuk aspek metode pembelajaran yang diterapkan oleh guru dan dosen diperoleh persentase sebesar $68,75 \%$ berada pada kategori rendah. Fokus pertanyaan diarahkan pada aspek metode ini adalah penggunaan metode pembelajaran yang sesuai dengan kemampuan mahasiswa, maka hasil tersebut menunjukkan bahwa penyampain materi oleh dosen tanpa menyesuaikan kemampuan mahasiswa memiliki peran yang sangat besar dalam memunculkan kesulitan terhadap penguasaan konsep-konsep geometri dimensi tiga pada mahasiswa calon guru matematika STKIP BBG.

Informasi lain berkaitan dengan penggunaan metode pembelajaran yang diperoleh dari hasil analisis angket dan wawancara adalah ketidakteraturan penyampaian materi oleh dosen menyebabkan $37,5 \%$ mahasiswa responden mengalami kebingungan saat pembelajaran berlangsung, ketika menjelaskan topik tertentu, tiba-tiba dosen sudah membahas topik lain lagi (dosen harus mengulang materi lain yang belum dikuasi mahasiswa yang terkait dengan topic yang sedang dibahas). Hal ini sesuai dengan apa yang disampaikan Syahrir et al. (2013) dalam penelitiannya dimana "jika pada saat terbentuk kesulitan siswa dalam pemahaman, guru mengulang pengetahuan dasar yang diperlukan, kemudian melanjutkan lagi materi baru yang pembelajarannya terpenggal tadi, merupakan salah satu factor yang sangat memingkinkan terjadinya kebingungan dan kesulitan pada siswa karena kurang trstrukturnya materi yang disampaikan oleh guru". Namun, responden yang lainnya menyebutkan bahwa proses pengulangan yang dilakukan oleh dosen membantu mereka dalam memahami materi baru yang sedang dijelaskan dosen.

Hal ini kemudian disimpulkan peneliti bahwa pada dasarnya proses pengulangan materi dasar ketika penyampaian materi baru dapat dilakukan oleh dosen maupun guru namun dengan tetap menjaga keteraturan materi yang disampaikan serta memastikan bahwa peserta didik memahami materi dasar tersebut dengan baik ketika melanjutkan menjelaskan materi baru tersebut. Karena berdasarkan penelitian ini, $62,5 \%$ responden yang merasa terbantu dengan penjelasan dosen mengenai materi dasar menyebutkan bahwa mereka akan dapat mengkoneksikan kembali pengetahuannya setelah proses pengulangan dilakukan. Selain itu, pengorganisasian struktur materi dalam suatu pembelajaran serta penyampaiannya yang dilakukan secara baik dan teratur juga sangat berpengaruh terhadap penguasaan siswa terhadap materi tersebut atau paling tidak dapat mengurangi kesulitan belajar dari siswa tersebut.

Untuk aspek fasilitas, lebih dari $75 \%$ responden menganggap bahwa fasilitas yang tersedia dalam mendukung pembelajaran geometri dimensi tiga pada tingkat perguruan tinggi berada pada kategori sangat tinggi, seperti penggunaan software matematika dalam pembelajaran geometri. Namun pemanfaatn fasilitas tersebut harus lebih dimaksimalkan lagi oleh tenaga dosen pengajar. Sedangkan untuk aspek kenyamanan ruang kelas lebih dari $56 \%$ berada pada kategori rendah. Terkait kenyamana ruang kelas, hasil wawancara diperoleh bahwa ruangan kelas yang terasa panas ketika pembelajaran berlangsung mengganggu konsentrasi mahasiswa dalam pembelajaran. Sehingga, faktor ini 
juga diduga dapat menjadi salah satu faktor yang menimbulkan kesulitan belajar.

Berdasarkan penjelasan tersebut, menunjukkan bahwa ditinjau dari aspek ekternal khususnya dari metode pembelajaran serta Kenyamanan ruangan yang masih tergolong rendah merupakan factor yang dapat diduga sebagai penyebab kesulitan belajar geometri dimensi tiga mahasiswa calon guru matematika STKIP BBG. Hasil penelitian ini juga mengidentifikasikan bahwa adanya kesenjangan tingkat pemahaman dan penguasaan konsep matematika khususnya aspek geometri dimensi tiga yang seharusnya dimiliki oleh peserta didik pada tingkat perguruan tinggi. Sehingga kesenjangan tersebut perlu dikaji lebih mendalam pada penelitian selanjutnya.

Sehingg disarankan bagi pengajar domain geometri di perguruan tinggi untuk dapat memperhatikan metode pembelajaran yang digunakan dengan kemampuan awal mahasiswa serta dapat membangkitkan minat mahasiswa untuk belajar. Hal ini sejalan dengan apa yang disampaikan oleh Romano (2017) yang mengungkapkan bahwa setiap mahasiswa calon guru matematika seharusnya diberi kesempatan untuk memperoleh pengalaman yang mencakup pengetahuan dasar mengenai konsep-konsep geometri. Mahasiswa calon guru matematika juga perlu diarahkan untuk memahami dan memperoleh pengetahuan tentang isu-isu penting pedagogik terkait pembelajaran geometri yang bermanfaat bagi mereka pada saat masuk kedunia kerja maupun dalam kehidupan sehari-hari. Romano (2017) juga menambahkan, penting sekali dalam pembelajaran geometri mahasiswa calon guru matematika diperkenalkan dan diberi kesempatan untuk mempelajari tentang tingkatan pemikiran geometry berdasarkan van Hiele sehingga secara independen mereka dapat mengevaluasi tingkat pemikiran geometri mereka sendiri.

Selanjutnya, dari segi sarana dan prasarana, sangat diharapkan bagi pihak pengelola perguruan tinggi untuk dapat memperhatikan pemenuhan dan kesiapan sarana dan prasarana yang dipakai dalam proses belajar dan pembelajaran.

\section{SIMPULAN}

Kesulitan belajar dalam memahami geometri dimensi tiga pada mahasiswa calon guru matematika STKIP BBG diakibatkan oleh dua faktor baik faktor internal maupun faktor ekternal. Faktor internal yang diduga sebagai penyebab kesulitan tersebut adalah rendahnya aspek minat, bakat dan intelegensi mahasiswa. Aspek intelegensi sangat dipengaruhi oleh rendahnya penguasan materi geometri dimensi tiga mahasiswa calon guru pada jenjang pendidikan sebelumnya. Sedangkan dari segi faktor ekternal, kesulitan belajar dipengaruhi oleh ketidaksesuainnya metode yang digunakan dengan kemampuan awal para mahasiswa calon guru matematika STKIP BBG serta kenyamanan ruang belajar yang masih berada pada kategori rendah.

\section{UCAPAN TERIMAKASIH}

Tim peneliti mengucapkan banyak terima kasih kepada Kemenristek Dikti yang telah memberikan dana hibah untuk mendanai penelitian ini. Selanjutnya, seluruh pihak sivitas academika di STKIP Bina Bangsa Getsempena yang telah menjadi bagian dari penelitian ini, baik sebagai subjek penelitia, observer, dan pemberian ijin melakukan penelitian.

\section{DAFTAR PUSTAKA}

Acharya, C., \& Ghose, A. (2015). Acquisition of basic geometric concepts among students who have completed class VIII. International Journal of Education and Psychological Research, 4(4), 91-98. Retrieved from http://ijepr.org/doc/V4_Is4_Dec15/ij20.pd $\mathrm{f}$

Ada, T., \& Kurtuluş, A. (2010). Students' misconceptions and errors in transformation geometry. International Journal of Mathematical Education in Science and Technology, 41(7), 901-909. https://doi.org/10.1080/0020739X.2010.4 86451

Ahmad, S. R. S. (2016). Pengaruh math phobia, self-efficacy, adversity quotient dan motivasi berprestasi terhadap prestasi belajar matematika siswa SMP. Jurnal Riset Pendidikan Matematika, 3(2), 259. https://doi.org/10.21831/jrpm.v3i2.6138

Aslan-Tutak, F., \& Adams, T. L. (2015). A study of geometry content knowledge of elementary preservice teachers. International Electronic Journal of Elementary Education, 7(3), 301-318. Retrieved from https://www.iejee.com/index.php/IEJEE/a rticle/view/82

Astutik, H. S. (2017). Keefektifan pembelajaran 
berdasarkan masalah pada bangun ruang sisi datar ditinjau dari penguasaan SK, motivasi, dan minat siswa SMP. Jurnal Riset Pendidikan Matematika, 4(1), 56. https://doi.org/10.21831/jrpm.v4i1.12722

Browning, C., Edson, A. J., Kimani, P., AslanTutak, F., \& Kimani, P. M. (2014). Mathematical content knowledge for teaching elementary mathematics: A focus on geometry and measurement. The Mathematics Enthusiast TME The Mathematics Enthusiast, 11(2), 333-384. Retrieved from https://scholarworks.umt.edu/tme/vol11/is s $2 / 7$

Clements, D. H., \& Sarama, J. (2011). Early childhood teacher education: The case of geometry. Journal of Mathematics Teacher Education, 14(2), 133-148. https://doi.org/10.1007/s10857-011-91730

Copeland, R. W. (1984). How children learn mathematics, teaching implications of Piaget's research. New York, N. Y.: The Macmillan Company.

Couto, A., \& Vale, I. (2014). Pre-service teachers' knowledge on elementary geometry concepts. Journal of the European Teacher Education Network, 9(0), 57-73. Retrieved from http://jetenonline.org/index.php/jeten/article/view/32

Dalyono, M. (2012). Psikologi pendidikan. Jakarta: Rineka Cipta.

Departemen Pendidikan dan Kebudayaan. (2012). Model kurikulum tingkat satuan pendidikan dan model pengembangan silabus mata pelajaran SMP/MTs. Jakarta: BP Cipta Jaya.

George, W. (2017). Bringing van Hiele and Piaget together: A case for topology in early mathematics learning. Journal of Humanistic Mathematics, 7(1), 105-116. https://doi.org/10.5642/jhummath.201701. 08

Hamalik, U. (2015). Metode belajar dan kesulitan-kesulitan belajar. Bandung: Tarsito.

Hwang, W.-Y., Su, J.-H., Huang, Y.-M., \& Dong, J.-J. (2009). A study of multirepresentation of geometry problem solving with virtual manipulatives and whiteboard system. Educational Technology \& Society, 12(3), 229-247.
Retrieved

from https://pdfs.semanticscholar.org/447e/895 15b54aa33eb7b6b4949b930e043fbc055.p df

Iswadji, D. (2001). Geometri ruang. Yogyakarta: Universitas Negeri Yogyakarta.

Kabaca, T., Karadag, Z., \& Aktumen, M. (2011). Misconception, cognitive conflict and conceptual changes in geometry: a case study with pre-service teachers. Mevlana International Journal of Education (MIJE), 1(2), 44-55.

Kamaliyah, K., Zulkardi, Z., \& Darmawijoyo, D. (2013). Developing the sixth level of PISA-like mathematics problems for secondary school students. Journal on Mathematics Education, 4(1), 9-28. https://doi.org/10.22342/jme.4.1.559.9-28

Kereh, C. T., Sabandar, J., \& Tjiang, P. C. (2013). Identifikasi kesulitan belajar mahasiswa dalam konten matematika pada materi pendahuluan fisika inti. In Prosiding Seminar Nasional Sains dan Pendidikan Sains VIII (Vol. 4, pp. 10-16). Salatiga: Universitas Kristen Setya Wacana . Retrieved from http://repository.uksw.edu/bitstream/1234 56789/3113/2/PROS_Cicylia TK, Jozua $\mathrm{S}$, Paulus $\mathrm{CT}_{-}$Identifikasi Kesulitan Belajar_Full text.pdf

Leung, K. C. I., Ding, L., Leung, A. Y. L., \& Wong, N. Y. (2013). Prospective teachers' competency in teaching how to compare geometric figures: The concept of congruent triangles as an example 1. In Proceedings of the KSME 2014 Spr. Conf. on Math. Educ (Vol. 3, pp. 545-558). Seoul: Hankuk U. of Foreign Studies,. Retrieved from http://210.101.116.28/W_files/kiss6/1030 $7666 \_p v . p d f$

National Research Council. (2009). Mathematics learning in early childhood. Washington, D.C.: National Academies Press. https://doi.org/10.17226/12519

Negoro, S. T., \& Harahap, B. (2014). Ensiklopedia matematika. Ghalia Indonesia.

Nitko, A. J., \& Brookhart, S. M. (2011). Educational assessment of students. New Jersey: Pearson/Allyn \& Bacon.

Novita, R., \& Niawati, N. (2016). Penerapan 
pendekatan kontekstual pada bangun ruang kubus dan balok di kelas VIII sekolah menengah pertama. Jurnal Numeracy, 3(1). Retrieved from $\mathrm{http} / / /$ numeracy.stkipgetsempena.ac.id/ho me/article/view/31

Nurhikmayati, I. (2017). Analisis kesulitan belajar mahasiswa pada matakuliah matematika dasar. Theorems, 2(1). Retrieved from http://jurnal.unma.ac.id/index.php/th/articl e/view/576

Ojose, B. (2008). Applying Piaget's theory of cognitive development to mathematics instruction. The Mathematics Educator, 18(1). Retrieved from http://tme.journals.libs.uga.edu/index.php/ tme/article/view/193

Özerem, A. (2012). Misconceptions in geometry and suggested solutions for seventh grade students. Procedia - Social and Behavioral Sciences, 55, 720-729. https://doi.org/10.1016/J.SBSPRO.2012.0 9.557

Panaoura, A. (2014). Using representations in geometry: a model of students' cognitive and affective performance. International Journal of Mathematical Education in Science and Technology, 45(4), 498-511. https://doi.org/10.1080/0020739X.2013.8 51804

Prahmana, R. C. I. (2017). Design research (Teori dan implementasinya: Suatu pengantar). Jakarta: Rajawali Pers.

Robichaux-Davis, R. R., \& Guarino, A. J. (2016). Assessing elementary pre-service teachers' knowledge for teaching geometry. International Journal of Mathematics and Statistics Invention, 4(1), 12-20. Retrieved from www.ijmsi.org

Rofii, A., Sunardi, S., \& Irvan, M. (2018). Characteristics of students' metacognition process at informal deduction thinking level in geometry problems. International Journal on Emerging Mathematics Education, 2(1), 89-104. https://doi.org/10.12928/ijeme.v2i1.7684

Romano, D. A. (2017). Prospective B\&amp;H elementary school teachers' understanding of processes with basic geometric concepts. Open Mathematical Education Notes, 7, 29-42. https://doi.org/10.7251/OMEN1701029R

Ryandi, R. B., Somakim, S., \& Susanti, E. (2018). Learning combinations through "Handshake." International Journal on Emerging Mathematics Education, 2(1), 105-118. https://doi.org/10.12928/ijeme.v2i1.8693

Sugiyono. (2015). Metode penelitian pendidikan: Pendekatan kuantitatif, kualitatif, dan $R \& D$. Bandung: Alfabeta.

Sutiarso, S., Nurhanurawat, N., \& Coesamin, M. (2008). Implementasi pembelajaran matematika dengan problem posing yang dikombinasikan dengan cooperative. Jurnal Pendidikan MIPA, 9(2), 30-35.

Syahrir, S., Kusnadin, K., \& Nurhayati, N. (2013). Analisis kesulitan pemahaman konsep dan prinsip materi pokok dimensi tiga siswa kelas XI SMK Keperawatan Yahya Bima. Prisma Sains: Jurnal Pengkajian Ilmu Dan Pembelajaran Matematika Dan IPA IKIP Mataram, 1(1), 89-103. Retrieved from http://ojs.ikipmataram.ac.id/index.php/pri smasains/article/view/522

The National Mathematics Advisory Panel. (2008). Foundations for success: The final report of the national mathematics advisory panel. Washington, DC.: Department of Education, Office of Planing. Evaluation and Policy Development. 